\title{
1 Emergence of the E484K Mutation in SARS-CoV-2 Lineage B.1.1.220 in Upstate New York
}

2 Emil Lesho $^{1 * \#}$, Brendan Corey $^{2 *}$, Francois Lebreton ${ }^{2}$, Ana C. Ong ${ }^{2}$, Brett E. Swierczewski ${ }^{2}$,

3 Jason W. Bennett ${ }^{2}$, Edward E. Walsh ${ }^{1,3}$, and Patrick Mc Gann ${ }^{2 \#}$

4

$5 \quad{ }^{1}$ Infectious Diseases Unit, Rochester General Hospital, Rochester, New York, USA

$6 \quad{ }^{2}$ Multidrug-Resistant Organism Repository and Surveillance Network (MRSN), Walter Reed

7 Army Institute of Research, Silver Spring, Maryland, USA

$8{ }^{3}$ University of Rochester School of Medicine, Rochester, NY

$10 *$ Emil Lesho and Brendan Corey contributed equally to this article

12 \#Corresponding author

13 Patrick Mc Gann, PhD

14 Walter Reed Army Institute of Research

15503 Robert Grant Avenue, 2A36

16 Silver Spring, MD 20910, USA

17 Email: patrick.t.mcgann4.civ@mail.mil
\# Alternate corresponding author

Emil P. Lesho, DO

Infectious Diseases Unit

Rochester General Hospital

Rochester, NY 14850, USA

Email:emil.lesho@rochesterregional.org 
medRxiv preprint doi: https://doi.org/10.1101/2021.03.11.21253231; this version posted March 23, 2021. The copyright holder for this preprint (which was not certified by peer review) is the author/funder, who has granted medRxiv a license to display the preprint in perpetuity.

It is made available under a CC-BY 4.0 International license.

\section{Abstract}

19 Ongoing surveillance detected a SARS-CoV-2 B.1.1.220 variant carrying the E484K substitution

20 in four patients from a hospital network in upstate New York. Patients reported no travel history

21 and shared no obvious epidemiological linkage. A search of online databases identified 12

22 additional B.1.1.220 with E484K, all of which were detected in New York since December 2020.

23 Detailed genomic analyses suggests that the mutation has emerged independently in at least two

24 different B.1.1.220 strains in this region. 
medRxiv preprint doi: https://doi.org/10.1101/2021.03.11.21253231; this version posted March 23, 2021. The copyright holder for this preprint (which was not certified by peer review) is the author/funder, who has granted medRxiv a license to display the preprint in perpetuity.

It is made available under a CC-BY 4.0 International license.

Severe acute respiratory syndrome coronavirus 2 (SARS-CoV-2), the etiological agent of coronavirus disease 2019 (COVID-19), has caused a global pandemic that is reshaping society. As part of an unprecedented global response from the scientific community the development and rapid deployment of multiple antibody-based countermeasures that target the viral spike protein has proceeded at an incredible pace.

Over the past six months, the emergence of three variants with mutations in the spike protein has raised serious concerns about the durability of the current suite of vaccines and immunotherapies. The variants, which are colloquially referred to as the United Kingdom (B.1.1.7 using the Pangolin nomenclature ${ }^{1}$ ), South African (B.1.351), and Brazilian (P.1) variants $^{2-4}$, have been increasingly identified worldwide ${ }^{5}$. The first variant (B.1.1.7) was identified in September 2020 and carries a N501Y mutation in the receptor-binding domain (RBD) of the spike protein ${ }^{4}$. Critically, recent studies have suggested this mutation potentially increases transmission and virulence ${ }^{6,7}$. Shortly thereafter, this same mutation was identified in B.1.351 and P. $1^{2,3}$. Both variants also carried an additional substitution (E484K) in the spike that can increase resistance to neutralization by many monoclonal antibodies (mAb), while most convalescent sera and mRNA vaccine-induced immune sera show reduced inhibitory activity ${ }^{8-11}$. Notably, interim results from the Novavax adjuvented spike protein nanoparticle COVID-19 vaccine trial indicated an efficacy of $85.6 \%$ against B.1.1.7 infection (versus $95.6 \%$ for the original strain), but just $49.4 \%$ to $60 \%$ in a South Africa Phase $2 \mathrm{~b}$ trial in which the B.1.351 strain was detected in the majority of COVID-19 events ${ }^{12}$.

In the United States, there have been 3,037 cases with the B.1.1.7 variant identified in 49 jurisdictions, 81 cases with B.1.351 (20 jurisdictions), and 15 cases with P.1 (9 jurisdictions) as 
medRxiv preprint doi: https://doi.org/10.1101/2021.03.11.21253231; this version posted March 23, 2021. The copyright holder for this preprint (which was not certified by peer review) is the author/funder, who has granted medRxiv a license to display the preprint in perpetuity.

It is made available under a CC-BY 4.0 International license .

48 of this writing (March 2021) ${ }^{13}$. In addition, several regional variants have been identified, such

49 as the 20C-US lineage in the Midwest ${ }^{14}$ and the B.1.2 lineage carrying the Q677P substitution in

50 New Mexico and Louisiana ${ }^{15}$. However, these lack the E484K and N501Y mutations. In

51 contrast, the recently described B.1.536 variant in New York City carries E484K ${ }^{16}$. Notably, this

52 variant has been spreading at an alarming rate since November and by February $15^{\text {th }} 2021$

53 accounted for $12.3 \%$ of all cases in this catchment area. Similar to previous studies with variants

54 carrying E484K, antibody neutralization by mAbs REGN10933, CB6, and LY-CoV555 are

55 either impaired or abolished with this variant ${ }^{16}$. Similarly, the neutralizing activities of

56 convalescent plasma or post-vaccination sera were lower by 7.7-fold and 3.4-fold, respectively ${ }^{16}$.

57 These data illustrate the alarming rise of this mutation, which has now been detected in 88 of 886

58 lineages (as of this writing), with various degrees of frequency ${ }^{5,17}$.

In June 2020, a pilot study to investigate SARS-CoV-2 was initiated between the Multi-

60 drug resistant organism Repository and Surveillance Network (MRSN) and the Rochester

61 Regional Health System; a network consisting of 8 acute care hospitals, 9 urgent care centers,

62 and 6 long-term care facilities in St Lawrence County and the 9-county Finger Lakes Region of

63 NY. Every hospital-based laboratory in the network is capable of testing for COVID-19 infection

64 and to date 438,107 samples have been tested with 25,468 distinct patients testing positive. For

65 this study, samples were provided by five hospitals in the Finger Lakes region. RNA is extracted

66 from SARS-CoV-2-positive nasopharyngeal swabs and transferred to the MRSN for sequencing

67 (See Methods). To date, >150 samples spanning April 2020 to February 2021 have been

68

analyzed, with 14 different Pangolin lineages identified (manuscript in preparation). Though

69

notable mutations were found in the spike proteins from these earlier samples, including D614G,

70 S673T, Q677H, N679K, and P681H, the E484K and N501Y substitutions were not identified. 
medRxiv preprint doi: https://doi.org/10.1101/2021.03.11.21253231; this version posted March 23, 2021. The copyright holder for this preprint (which was not certified by peer review) is the author/funder, who has granted medRxiv a license to display the preprint in perpetuity.

It is made available under a CC-BY 4.0 International license .

The most recent shipment consisted of 20 samples from 19 patients collected between

72 January $27^{\text {th }}$ and February $7^{\text {th }}, 2021$. Upon analysis, the E484K substitution was detected in five

73 samples from one male and three female patients. The average age was 85 years (range 74-92)

74 and, despite advanced age and multiple co-morbidities (mean CALL score $=10)^{18}$, all recovered.

75 Three patients had mild courses with no specific anti-SARS-CoV-2 treatments. One patient

76 received Remdesivir and Dexamethasone and did not require intensive care or endotracheal

77 intubation. Notably, three patients lived in separate assisted living facilities with no known

78 connections and the fourth resided at home. All patients reported no significant travel in the

79 preceding 6 months.

The five strains were assigned to Pangolin Lineage B.1.1.220 (NextStrain clade 20B;

81 Figure 1A), a globally distributed lineage that has also been identified in 2-7\% of COVID-19

82 cases in the North-East US (Figure 1B). In addition to the E484K substitution, the strains carried

83 the characteristic 4 amino acid substitutions that define this lineage when compared to the

84 Wuhan-Hu-1 SARS-CoV-2 reference genome (NCBI GenBank Acc. MN908947), namely

85 R203K, G204R, P314L and D614G. This latter substitution has become the most prevalent

86 mutation world-wide and studies suggest it increases viral transmissibility and results in higher

87 viral loads ${ }^{19,20}$. To better understand the relationship between the 5 samples we performed a

88 whole genome high-resolution single nucleotide polymorphism (SNP) based comparison. The

89 two samples from the same patient were genetically identical (0 SNPs), but the remaining

90 samples were separated by 1-4 SNPs.

Analysis of the five variants in the open data software at MicroReact ${ }^{21}$ identified 6

92 additional B.1.1.220 variants with the E484K substitution. All were deposited by the Wadsworth

93 Center (Albany, NY), a sentinel institute of the New York Department of Health. Further 
medRxiv preprint doi: https://doi.org/10.1101/2021.03.11.21253231; this version posted March 23, 2021. The copyright holder for this preprint (which was not certified by peer review) is the author/funder, who has granted medRxiv a license to display the preprint in perpetuity.

It is made available under a CC-BY 4.0 International license .

comparative analysis with 124 B.1.1.220 sequences from the New York region deposited at GISAID identified an additional 6 variants with this mutation. Surprisingly, a phylogenetic analysis suggested that the E484K substitution has arisen independently at least twice within Lineage B.1.1.220 in the New York region, as evidenced by the significant genetic separation (25 to 29 SNPs) between a monophyletic cluster of 16 samples from Central and Western New York and sample 1098129 from the New York Metropolitan area (Figure 1C, Table S1). Zoomed-in analysis of the 16 monophyletic strains revealed high-genetic relatedness (0-7 SNPs) and further suggested that this B.1.1.220 E484K variant has just recently emerged and is rapidly spreading across New York State with isolates being collected from at least 6 distinct counties between December and February 2020 (Figure 1D). Importantly, as of this writing (March 2021) the only B.1.1.220 variants shown to harbor the E484K mutation have been isolated in New York.

To the best of our knowledge, this is the first report of a Lineage B.1.1.220 bearing the important E484K mutation. The observed mutational convergence within the relatively small subset of Lineage B.1.1.220 genomes from New York State further indicates that codon S/484 is evolving under a strong degree of positive selection. Though not supported statistically, it is notable that no B.1.1.220 variants were detected in our surveillance effort prior to December 2020 when it suddenly comprised $25 \%$ of the late January and early February samples.

However, as of this writing (March 2021), only 146 B.1.1.220 genomes from NY have been uploaded to GISAID, with the majority $(n=87)$ collected since January $1^{\text {st }}, 2021$; additional B.1.1.220 sequences from this region are required to better understand the current distribution and apparent emergence of this concerning variant. It will also be important to assess how the E484K mutation affects protection by vaccines against this specific variant that lacks the other 
medRxiv preprint doi: https://doi.org/10.1101/2021.03.11.21253231; this version posted March 23, 2021. The copyright holder for this preprint (which was not certified by peer review) is the author/funder, who has granted medRxiv a license to display the preprint in perpetuity.

It is made available under a CC-BY 4.0 International license.

117 mutations in the B1.351 and P1 strains. As the vaccine roll-out gathers pace across the United

118 States, it is imperative that every means necessary are employed to rapidly identify the

119 emergence of variants-of-concern and immediate action taken to limit their spread. 
medRxiv preprint doi: https://doi.org/10.1101/2021.03.11.21253231; this version posted March 23, 2021. The copyright holder for this preprint (which was not certified by peer review) is the author/funder, who has granted medRxiv a license to display the preprint in perpetuity.

It is made available under a CC-BY 4.0 International license .

\section{Methods}

\section{Sequencing of SARS-CoV-2 samples}

Viral RNA was extracted from nasopharyngeal swabs using the QIAamp Viral RNA Mini Kit (Qiagen, 52906). RNA was converted to cDNA and enriched for SARS-CoV-2 using the QIAseq SARS-CoV-2 Primer Panel (Qiagen, 333896). Libraries were constructed using the KAPA HyperPlus kit (Roche, KK8514), quantified with the KAPA Library Quantification kit (Roche, KK44), pooled, denatured and diluted to $14 \mathrm{pM}$. The diluted sample was sequenced on an Illumina MiSeq sequencer using a MiSeq v3 (600 cycle) Reagent Kit (Illumina, MS-102-3003).

\section{Bioinformatic Analysis of SARS-CoV-2 genomes}

Miseq read data was trimmed for adapters and low quality sequence using BBduk v38.79 (https://sourceforge.net/projects/bbmap/). Trimmed reads were then mapped to the Wuhan-Hu-1 SARS-CoV-2 reference genome (NCBI GenBank Acc. MN908947) using Snippy v4.4.5 (https://github.com/tseemann/snippy). BAM files were imported into Geneious ${ }^{22}$ where variants identified by Snippy were manually curated/confirmed. Nucleotide alignments were performed with Muscle ${ }^{23}$ followed by trimming of ambiguous/under-represented sequence at the 5'/3' ends of the alignment in Geneious. Genome-based, maximum likelihood phylogenies were produced with RAxML-ng (model GTR+Gamma, 50 parsimony, 50 random) ${ }^{24}$. Best scoring phylogenetic trees were selected and edited using iTOL ${ }^{25}$.

\section{Use of GISAID, Microreact, NextStrain, Outbreak.info and Pangolin Resources.}

Lineage assignment was performed using the Pangolin online web application ${ }^{1}$. Identification of additional B.1.1.220 lineage samples with and without the E484K mutation was performed initially with Microreact ${ }^{21}$ and later with GISAID ${ }^{26}$. An acknowledgement of the originating and 
medRxiv preprint doi: https://doi.org/10.1101/2021.03.11.21253231; this version posted March 23, 2021. The copyright holder for this preprint (which was not certified by peer review) is the author/funder, who has granted medRxiv a license to display the preprint in perpetuity.

It is made available under a CC-BY 4.0 International license .

142 submitting laboratories providing the SARS-CoV-2 comparator genomes used in this study can

143 be found in the Supplemental Material (Table S1 and S2).

144 The time-scaled analysis of SARS-CoV-2 genomes (Fig. 1A) was modified from the Nextstrain ${ }^{27}$

145 SARS-CoV-2 global phylogeny (https://nextstrain.org/ncov/global) accessed on March $6^{\text {th }}, 2021$.

146 This build contained 3,960 SARS-CoV-2 genomes sampled between Dec 2019 and Mar 2021

147 and collected from: Africa $(n=588)$, Asia $(n=671)$, Europe $(n=783)$, North America $(n=845)$,

148 Oceania $(n=489)$ and South America $(n=594)$. Full details on bioinformatic processing are

149 available on the Nexstrain Github page (https://github.com/nextstrain/ncov).

150 The USA map of the estimated Lineage B.1.1.220 prevalence (Fig. 1B) was created and edited

151 from the Outbreak.info ${ }^{17}$ dashboard accessed on March $7^{\text {th }}, 2021$.

152 Data submission

153 The sequences of the five strains described in this paper have been uploaded to GISAID with

154 Accession ID (virus name): EPI_ISL_1184113(hCoV-19/USA/NY-RRHS-101/2021),

155 EPI_ISL_1184114 (hCoV-19/USA/NY-RRHS-102/2021), EPI_ISL_1184135 (hCoV-

156 19/USA/NY-RRHS-114/2021), EPI_ISL_1184136 (hCoV-19/USA/NY-RRHS-115/2021), and

157 EPI_ISL_1184137 (hCoV-19/USA/NY-RRHS-120/2021). 
medRxiv preprint doi: https://doi.org/10.1101/2021.03.11.21253231; this version posted March 23, 2021. The copyright holder for this preprint (which was not certified by peer review) is the author/funder, who has granted medRxiv a license to display the preprint in perpetuity.

It is made available under a CC-BY 4.0 International license .

\section{Acknowledgements}

159 We are deeply indebted to the clinical and research laboratories of the Rochester Regional Health

160 System and ACM Global Laboratories, especially Maria Formica, Julie Freed, Chalece Holland,

161 Jean Campbell, and Julia Nary.

162 This study was partially funded by the Defense Health Program (DHP) Operations \&

163 Maintenance (O\&M). Material has been reviewed by the Walter Reed Army Institute of

164 Research. There is no objection to its presentation. The opinions or assertions contained herein

165 are the private views of the authors and are not to be construed as official, or reflecting the views

166 of the Department of the Army or the Department of Defense. Some authors (Bennett, Mc Gann,

167 Swierczewski) are employees of the U.S. Government and this work was prepared as part of

168 their official duties. 
medRxiv preprint doi: https://doi.org/10.1101/2021.03.11.21253231; this version posted March 23, 2021. The copyright holder for this preprint (which was not certified by peer review) is the author/funder, who has granted medRxiv a license to display the preprint in perpetuity.

It is made available under a CC-BY 4.0 International license.

\section{Bibliography}

1. Rambaut, A., et al. A dynamic nomenclature proposal for SARS-CoV-2 lineages to assist genomic epidemiology. Nat Microbiol 5, 1403-1407 (2020).

2. Houriiyah Tegally., et al. Emergence and rapid spread of a new severe acute respiratory syndrome-related coronavirus 2 (SARS-CoV-2) lineage with multiple spike mutations in South Africa. MedRxiv (2020). DOI: https://doi.org/10.1101/2020.12.21.20248640.

3. Nuno R., et al. Genomics and epidemiology of a novel SARS-CoV-2 lineage in Manaus, Brazil. (2021). DOI: https://doi.org/10.1101/2021.02.26.21252554.

4. Rambaut, A., et al. Preliminary genomic characterization of an emergent SARS-CoV-2 lineage in the UK defined by a novel set of spike mutations. Unpublished: https://virological.org/t/preliminary-genomic-characterisation-of-an-emergent-sars-cov-2lineage-in-the-uk-defined-by-a-novel-set-of-spike-mutations/563.

5. O'Toole, Á et al. Pangolin: lineage assignment in an emerging pandemic as an epidemiological tool. (2021). Unpublished: github.com/cov-lineages/pangolin

6. Davies, N.G., et al. Estimated transmissibility and impact of SARS-CoV-2 lineage B.1.1.7 in England. Science (2021). Epub ahead of print: 2021/03/05

7. Volz, S.M., et al. Transmission of SARS-CoV-2 Lineage B.1.1.7 in England: Insights from linking epidemiological and genetic data. medRxiv (2021). DOI: https://doi.org/10.1101/2020.12.30.20249034.

8. Chen, R.E., et al. Resistance of SARS-CoV-2 variants to neutralization by monoclonal and serum-derived polyclonal antibodies. Nat Med (2021). Epub ahead of print: 2021/03/06. 
191 9. Daming Zhou, W.D., et al. Evidence of escape of SARS-CoV-2 variant B.1.351 from natural and vaccine induced sera. Cell (2021). DOI: https://doi.org/10.1016/j.cell.2021.02.037.

194 10. Wang, W.B., et al.. E484K mutation in SARS-CoV-2 RBD enhances binding affinity with hACE2 but reduces interactions with neutralizing antibodies and nanobodies: Binding free energy calculation studies. bioRxiv (2021). DOI: https://doi.org/10.1101/2021.02.17.431566.

198 11. Weisblum, Y., et al. Escape from neutralizing antibodies by SARS-CoV-2 spike protein 199 variants. Elife 9 (2020).

12. Novavax. Novavax COVID-19 Vaccine Demonstrates $89.3 \%$ Efficacy in UK Phase 3 Trial. Press release: https://ir.novavax.com/news-releases/news-release-details/novavaxcovid-19-vaccine-demonstrates-893-efficacy-uk-phase-3. (2021).

203 13. United States Centers for Disease Control. US COVID-19 Cases Caused by Variants. https://www.cdc.gov/coronavirus/2019-ncov/transmission/variant-cases.html. (2021). the United States. bioRxiv (2021). DOI: https://doi.org/10.1101/2021.01.11.426287

207 15. Hodcroft, E.B., et al. Emergence in late 2020 of multiple lineages of SARS-CoV-2 Spike protein variants affecting amino acid position 677. medRxiv (2021). DOI: https://doi.org/10.1101/2021.02.12.21251658. 
medRxiv preprint doi: https://doi.org/10.1101/2021.03.11.21253231; this version posted March 23, 2021. The copyright holder for this preprint (which was not certified by peer review) is the author/funder, who has granted medRxiv a license to display the preprint in perpetuity.

It is made available under a CC-BY 4.0 International license .

213 18. Ji, D., et al. Prediction for Progression Risk in Patients With COVID-19 Pneumonia: The

214 CALL Score. Clin Infect Dis 71, 1393-1399 (2020).

215 19. Jackson, C.B., Zhang, L., Farzan, M. \& Choe, H. Functional importance of the D614G

216 mutation in the SARS-CoV-2 spike protein. Biochem Biophys Res Commun 538, 108-115

217 (2021).

218 20. Korber, B., et al. Tracking Changes in SARS-CoV-2 Spike: Evidence that D614G

219 Increases Infectivity of the COVID-19 Virus. Cell 182, 812-827 e819 (2020).

220 21. Argimon, S., et al. Microreact: visualizing and sharing data for genomic epidemiology

221 and phylogeography. Microb Genom 2, e000093 (2016).

222 22. Kearse M, et al.,. Geneious Basic: an integrated and extendable desktop software

223 platform for the organization and analysis of sequence data. Bioinformatics. 2012 Jun

$224 \quad 15 ; 28(12): 1647-9$.

225 23. Edgar RC. MUSCLE: multiple sequence alignment with high accuracy and high

226 throughput. Nucleic Acids Res. 2004 Mar 19;32(5):1792-7.

227 24. Kozlov AM, et al.,. RAxML-NG: a fast, scalable and user-friendly tool for maximum

228 likelihood phylogenetic inference. Bioinformatics. 2019 Nov 1;35(21):4453-4455.

229 25. Letunic I, Bork P. Interactive Tree Of Life (iTOL) v4: recent updates and new

230 developments. Nucleic Acids Res. 2019 Jul 2;47(W1):W256-W259.

231 26. Elbe S \& Buckland-Merrett G. Data, disease and diplomacy: GISAID's innovative 232 contribution to global health. Glob Chall. 2017 Jan 10;1(1):33-46.

233 27. Hadfield J, et al.,. Nextstrain: real-time tracking of pathogen evolution. Bioinformatics. 2342018 Dec 1;34(23):4121-4123. 
medRxiv preprint doi: https://doi.org/10.1101/2021.03.11.21253231; this version posted March 23, 2021. The copyright holder for this preprint (which was not certified by peer review) is the author/funder, who has granted medRxiv a license to display the preprint in perpetuity.

It is made available under a CC-BY 4.0 International license .

\section{Figure Legend}

\section{Figure 1. Emergence of the E484K mutation in B.1.1.220 SARS-CoV-2 isolates from}

Upstate New York. (A) Time-scaled, global phylogeny of 3,960 SARS-CoV-2 genomes

sampled between Dec 2019 and Mar 2021 (modified from Nextstrain ${ }^{27}$ dashboard). A full table

S2). Major clades (Nextstrain nomenclature), variants (literature) and lineages (Pangolin) are

248 of the spike protein while filled circles indicate those with Lysine $(\mathrm{K})$ at that position. Genomes obtained from GISAID ${ }^{26}$ (Table S1) are shown in red. Genomes newly described in this report are shown in blue (note that only four out of five circles are visible as two samples from a single SNPs separating each strain can be inferred from the respective scale. 
A

B

B.1.1.220
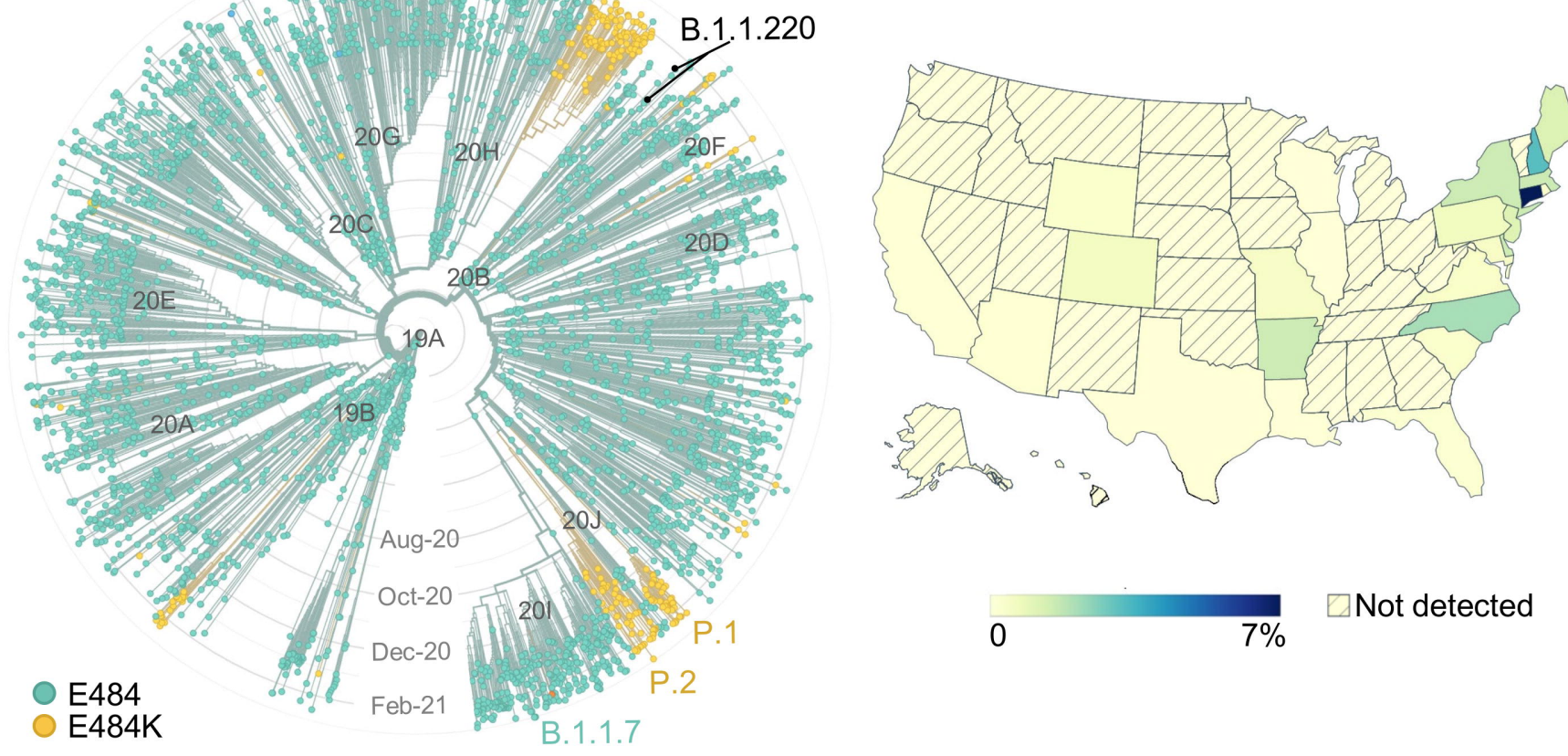

C

D

E484, GISAID
E484K, GISAID
E484K, Rochester Regional

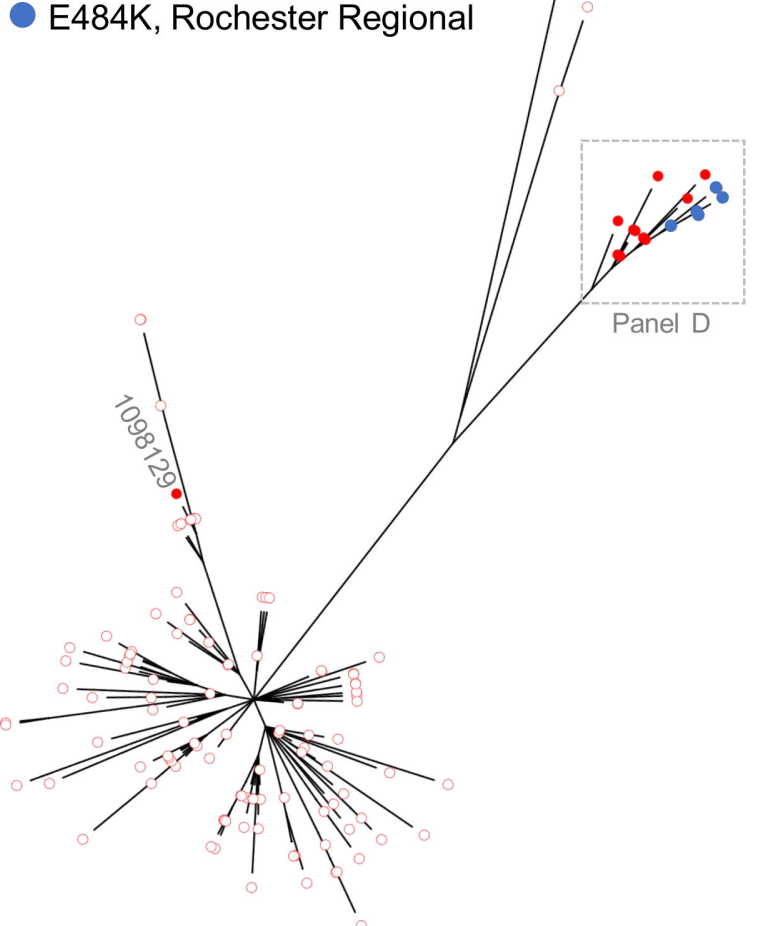

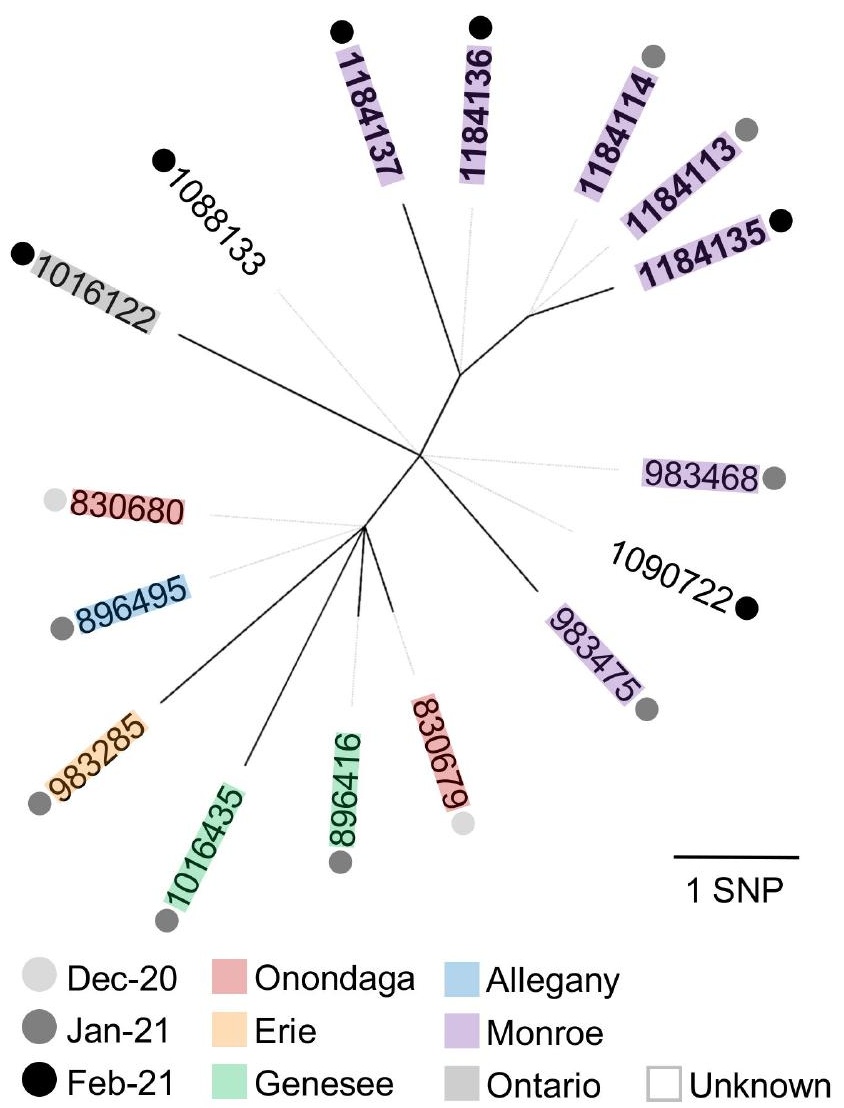

